\title{
Hygroscopic balance in pumpkin seeds
}

\section{Gustavo Soares Wenneck ${ }^{1}$, Reni Saath ${ }^{1}$, Danilo Cesar Santi ${ }^{1}$, Larissa Leite de Araújo ${ }^{1}$, Josélia Portilho dos Santos ${ }^{1}$, Giovanna Gabriela Ferreira de Oliveira ${ }^{1}$}

\author{
${ }^{1}$ Universidade Estadual de Maringá, Campus Sede, Maringá, Paraná, Brasil. E-mail: gustavowenneck@ gmail.com, \\ reniagricola@yahoo.com.br, danilosantiagro@gmail.com, larissa_leite_araujo@hotmail.com, joseliabrando@gmail.com, \\ ra106907@uem.br
}

Received: 27/11/2019; Accepted: 06/05/2020.

\begin{abstract}
The commercial exploitation of pumpkin seeds, at the flour form toasted or to the production of oil, requires knowledge about the activity of water and equilibrium moistures. This study aimed to determine the equilibrium isotherms to the pumpkin seeds and describe the dynamics of the process upon its physicochemical quality. With the static method, the equilibrium isotherms were determined for different temperatures and activities of water (0.110 to 0.885 dry basis), provided conditions by the conditioner chamber of atmosphere, with the weighing of the samples until the constant mass. The hygroscopic balance of the seeds was directly proportional to the activity of water and decreased with increasing temperature, for the same value of water activity. The pumpkin seeds maintained the water volume $(<0.10)$ at the storage conditions (relative humidity $<25 \%$ ). The modified Halsey model better represented the hygroscopicity of pumpkin seeds.
\end{abstract}

Keywords: water activity, Cucurbita spp., physical parameters, post-harvest, agricultural waste.

\section{Balanço higroscópico em sementes de abóbora}

\section{RESUMO}

A exploração comercial de sementes de abóbora, na forma de farinha torrada ou para produção de óleo, requer conhecimento sobre a atividade de água e umidade de equilíbrio. Na pesquisa, objetivou-se determinar as isotermas de equilíbrio das sementes de abóbora e descrever a dinâmica do processo sobre a qualidade físico-química. Utilizando método estático, o equilíbrio isotérmico foi determinado para diferentes temperaturas e atividade de água (0,110 a 0,885 base seca), proveniente de condições de embalagens herméticas, com pesagem das amostras até atingir massa constante. $\mathrm{O}$ balanço higroscópico das sementes foi diretamente proporcional à atividade da água e reduziu com o aumento da temperatura, para um mesmo valor de atividade de água. As sementes de abóbora mantiveram volume de água $(<0,10)$ nas condições de armazenamento (umidade relativa $<25 \%$ ). O modelo de Halsey modificado melhor representou a higroscopicidade das sementes de abóbora.

Palavras-chave: atividade de água, Cucurbita spp., parâmetros físicos, pós-colheita, resíduos agrícolas. 


\section{Introduction}

Belonging to the Cucurbitaceae Family and the genus Cucurbita, pumpkin is one of the most important vegetables in Brazil, standing out for its commercial importance (Santos Júnior et al., 2017). Pumpkin seeds are used for fresh or toasted consumption or in flour form, oil production, and as a culinary ingredient (Diógenes et al., 2013; Martins et al., 2016).

As for potentialities, pumpkin cultivation applies to family farming policies, as it is a plant with multiple uses in agriculture, such as small farmers can grow it for seed by-products; socioeconomically as an ingredient in the elaboration of diets serving care programs in underserved regions. Thus, to consolidate economic success and justify investment in the crop, it is necessary to know the influence of environmental conditions on product stability and major post-harvest operations, to provide correct conservation of the qualitative characteristics of the product.

Given this requirement, by eliminating water from the material through evaporation, drying is a way to minimize losses, enabling transport, storage, and increased shelf life, ensuring economic viability and microbiological safety (Diógenes et al., 2013). The drying process allows prolonging the preservation of the product, stability of the aromatic components at room temperature for different periods, protection against enzymatic and oxidative degradation, weight reduction, and energy-saving (Pereira and Damaceno, 2018; Thode Filho et al., 2014; Costa et al., 2015).

Water content has considerable influence on processing variables, characterization, and stability of these products (Belmiro et al., 2010; Ullmann et al., 2016). Water adsorption and desorption isotherms that indicate the interaction between water and the material where water is present (Barbosa et al., 2016), evidence of how strong the bond between water and adsorbate is according to temperature and pressure (Silva et al., 2015).

At constant temperature, variations in seed water content until equilibrium with water vapor in the surrounding air can be expressed by equilibrium curves (isotherms) or mathematical models (Bustos-Vanegas et al., 2018). Relative humidity and temperature conditions during storage, where the product reaches the specific hygroscopic equilibrium, regardless of time, will determine the maintenance of its qualitative potential (Costa et al., 2013; Dalpasquale et al., 2012; Guimarães et al., 2018; Silva et al., 2015).

Hygroscopicity of pumpkin seeds indicates the relationship between water and its chemical components, where water activity refers to its availability for physical, chemical, and microbiological changes in each period considered, influenced by the handling, storage, and consumption process. In this context, the study of the sorption curve provides relevant information for the adequacy of drying parameters, and the study of water activity as a tool in processes and analysis of biological materials to indicate product quality and stability.

The study aimed to determine its hygroscopic balance from different controlled conditions of temperature and relative humidity well as to evaluate the dynamics of the process on the physic-chemical quality from the seed to analyze the sorption dynamics of pumpkin seed.

\section{Material and Methods}

The seeds were obtained from pumpkin fruits harvested at the Technical Center of Irrigation (CTIUEM), they were taken to the Laboratory of Medicinal Plants and Agricultural Product Processing of the Department of Agronomy (DAG-UEM). Where 15 days after harvest, the seeds manually extracted from the fruits and cleaned under running water.

The seeds with an initial water volume of \pm 0.1 on a dry basis $(\mathrm{db})$ were standardized in forced air circulation oven $\left(35{ }^{\circ} \mathrm{C}\right)$ to keep the determination of the hygroscopic balance of the pumpkin seeds under different temperature conditions and the relative humidity of the air. With uniform content of water, the seeds were placed in airtight structures containing different saturated chemical solutions of potassium hydroxide $(\mathrm{KOH})$, potassium acetate $\left(\mathrm{CH}_{2} \mathrm{CO}_{2} \mathrm{~K}\right)$, potassium carbonate $\left(\mathrm{K}_{2} \mathrm{CO}_{3}\right)$, magnesium chloride $\left(\mathrm{MgCl}_{2}\right)$, calcium nitrate $\left(\mathrm{Ca}\left(\mathrm{NO}_{3}\right)\right)$, sodium chloride $(\mathrm{NaCl})$, potassium chloride $(\mathrm{KCl})$ and barium chloride $\left(\mathrm{BaCl}_{2}\right)$, which in balance, condition an environment with different relative moistures (Greenspan, 1977), depending on the imposed temperature.

For the determination of desorption isotherms of fresh pumpkin seeds by the static gravimetric method under different conditions, it was used a forced-air circulation oven for the temperatures above $40{ }^{\circ} \mathrm{C}$; and a BOD (Biochemical Oxygen Demand) incubator for temperatures below $40{ }^{\circ} \mathrm{C}$.

The experiment with water activities $\left(\mathrm{a}_{\mathrm{w}}\right)$, ranging from 0.0925 to $0.9108(\mathrm{db})$, was conducted in airtight glass containers containing eight-salt saturated solutions (Table 2). The samples were composed of ten seeds (nylon bags) in triplicate and placed in airtight containers (saturated solution and seeds). The containers were transferred to a forced-air circulation oven $(40,43,50,60$ and $\left.70{ }^{\circ} \mathrm{C}\right)$ and BOD incubator $\left(10{ }^{\circ} \mathrm{C}, 20^{\circ} \mathrm{C}, 25^{\circ} \mathrm{C}\right.$; $15 / 35{ }^{\circ} \mathrm{C}(12 / 12 \mathrm{~h})$ and $\left.35^{\circ} \mathrm{C}\right)$ at the set temperature conditions.

The seeds were weighed at intervals of seven days until reach the constant mass to find the time required for the pumpkin seed to reach the hygroscopic balance. When reaching equilibrium, the seeds had their water content determined by the dry forced ventilation method 
at $103{ }^{\circ} \mathrm{C}$ for 24 hours, in duplicates (AOAC, 2019). Analyzing the moment the hygroscopic equilibrium occurs, the water activity (aw) equals the relative humidity in decimal (RH). Thus, for data analysis for each temperature, with Equation 12, the equilibrium humidity $(\mathrm{EH})$ was calculated.

$$
E H=\left\{\frac{\mathrm{M}_{e}-M_{S}}{M_{S}}\right\} \times 100
$$

(equation 12)
Where, EH: equilibrium humidity; Me: mass of product at the start of the sorption process $(\mathrm{g})$; Ms: mass of product at the end of the sorption process $(\mathrm{g})$.

Physicochemical seed characteristics were evaluated through electrical conductivity tests (Oliveira et al., 2012), and evaluation of orthogonal axes of pumpkin seeds (Figure 1), according to the methodology described by Mohsenin (1986) to associate the influence of environmental conditions on pumpkin seed stability.

Table 1. Model of CHUNG PFOST; COPACE; GAB; Modified GAB; Modified HALSEY; HENDERSON; Modified HENDERSON; OSWIN; SABBAB; SIGMA-COPACE and PELEG.

\begin{tabular}{|c|c|c|}
\hline Model & Equation & Number \\
\hline CHUNG PFOST & $U_{e}=a-b \ln \left[-(T+c) \ln \left(a_{w}\right)\right]$ & (1) \\
\hline COPACE & $U_{e}=\exp \left[a-(b T)+\left(c a_{w}\right)\right]$ & (2) \\
\hline GAB & $U_{e}=\frac{X_{m} c K a_{w}}{\left(1-K a_{w}\right)\left(1-K a_{w}+c K a_{w}\right)}$ & (3) \\
\hline Modified GAB & $U_{e}=\frac{a b\left(\frac{c}{T}\right) a_{w}}{\left\{\left[1-b a_{w}\right]\left[1-b a_{w}+b\left(\frac{c}{T}\right) a_{w}\right]\right\}}$ & (4) \\
\hline Modified HALSEY & $U_{e}=\left[\frac{\exp (a-b T)}{-\ln \left(a_{w}\right)}\right]^{\frac{1}{c}}$ & (5) \\
\hline HENDERSON & $U_{e}=\left[\frac{\ln \left(1-a_{w}\right)}{\left(-\mathrm{a} T_{a b s}\right)}\right]^{\frac{1}{c}}$ & (6) \\
\hline Modified HENDERSON & $U_{e}=\left\{\frac{\ln \left(1-a_{w}\right)}{[-\mathrm{a}(\mathrm{T}+\mathrm{b})]}\right\}^{\frac{1}{c}}$ & (7) \\
\hline OSWIN & $U_{e}=\frac{(a-b T)}{\left[\left(1-a_{w}\right) / a_{w}\right]^{\frac{1}{c}}}$ & (8) \\
\hline SABBAB & $U_{e}=a\left(a_{w} b / T^{c}\right)$ & (9) \\
\hline SIGMA COPACE & $U_{e}=\exp \left\{a-(b T)+\left[c \exp \left(a_{w}\right)\right]\right\}$ & (10) \\
\hline PELEG & $U_{e}=k_{1}\left(a_{w}^{n_{1}}\right)+k_{2}\left(a_{w}^{n_{2}}\right)$ & (11) \\
\hline
\end{tabular}

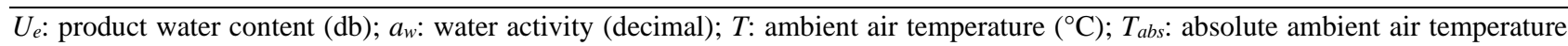
$(\mathrm{K}) ; \mathrm{X}_{\mathrm{m}}$ : moisture in the molecular monolayer $(\mathrm{db}) ; \mathrm{K}, \mathrm{C}, \mathrm{k}_{1}, \mathrm{k}_{2}, \mathrm{n}_{1}, \mathrm{n}_{2} ; a, b, c$ : parameters that depend on the product.
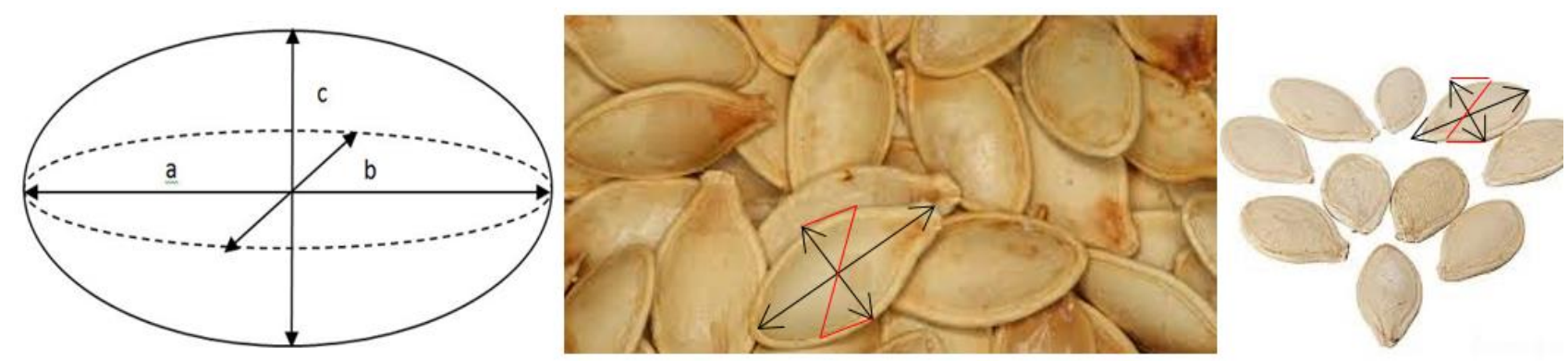

Figure 1. Schematic representation of pumpkin seed axes, considered triaxial spheroid, with its characteristic dimensions. 
Experimental data of hygroscopic equilibrium and information regarding the physical properties and qualitative indices of pumpkin seeds were adjusted in mathematical models (Table 1), using the STATISTICA $8.0 ®$ software through nonlinear regression analyzes estimated by the Quasi-Newton method. It was used the coefficient of determination $\left(\mathrm{R}^{2}\right)$, the relative mean error (P) and the standard deviation of estimate (SE), whose significance level of regression, together with the values of $\mathrm{R}^{2}$, by the $\mathrm{t}$-test, served as parameters for model selection to determine the adequate fit of each equation to the experimental data $(\mathrm{p}<0.05)$.

\section{Results and Discussion}

As for the determination of the hygroscopicity of pumpkin seeds, airtight containers containing different saturated solutions, which in equilibrium, conditioned a controlled environment with different relative humidity, depending on the imposed temperature were used (Table 2 ). From the mass difference, the respective hygroscopic equilibrium points were determined.

It was found that the equilibrium water content decreases with increasing temperature for given water activity, similar to hygroscopic products. Also, for constant water activity, the hygroscopic equilibrium water content values of pumpkin seeds decreased with increasing temperature (Table 3).

It is noted that the equilibrium humidity of pumpkin seeds decreases with decreasing water activity for all temperatures studied, demonstrating the water loss capacity of the samples.

In general, the use of sorption isotherms generates information regarding proper storage and decisions making about preventive measures to maintain product quality. Water activity at relative humidity above $70 \%$ indicates possible physicochemical changes from processing and relates to mechanisms that may deteriorate the seed (Yang et al., 2012; Veronezi and Jorge, 2012; Severino et al., 2019; Saath et al., 2019). Also, it was verified that the ambient temperature influenced the equilibrium humidity values, which decreased with the increase of the temperature to certain water activity.

According to the behavior of the experimental data of pumpkin hygroscopicity and estimated equilibrium humidity parameters, simulations performed with different mathematical models (Table 4).

Through equilibrium humidity equations, it was found that pumpkin seeds achieved hygroscopic equilibrium in each environment when they had a water content in $\mathrm{db}$ of less than $12 \%$. With water activity $\left(\mathrm{a}_{\mathrm{w}}\right)$ ranging from 0.0225 to $0.9708(\mathrm{db})$ according to the constant relative air humidity, the time needed for pumpkin seeds to reach hygroscopic equilibrium (Table 3 ), the respective $a_{w}$ for the saturated $\mathrm{KOH}$ solution presented the largest variation in seed water content ( $\mathrm{db}$ ) between treatments (temperatures). It was not observed significant variation for saturated $\mathrm{MgCl} 2$ solution. The variation between values for the same solution is attributed to the effect of temperature on salt. The variation between the different salts suggests the influence of the environment or the interaction.

In decimal result analysis, models with $\mathrm{R} 2$ distant from the unit and with $\mathrm{P}$ higher than $10 \%$ do not fit satisfactorily with the experiment (Teixeira et al., 2018). Based on statistical parameters, it was found that all models tested represented the seed desorption isotherms, with $\mathrm{R}^{2}$ higher than $83.98 \%$ suggesting a good representation of the pumpkin seeds hygroscopicity phenomenon, similar to the observations reported by Teixeira et al. (2018). It was found that the Copace $\left(\mathrm{R}^{2}=\right.$ $0.98)$ and modified Halsey $\left(\mathrm{R}^{2}=0.98\right)$ models had better representativeness in the phenomenon for the different temperatures (Table 5).

The simulation coefficient of determination (R2), the relative mean error percentage $(\mathrm{P})$, and the estimated mean error analyzed were considered as specific criteria concerning the representativeness analysis of the data to the proposed models. Based on the values $\left(\mathrm{R}^{2}, \mathrm{P}, \mathrm{SE}\right)$, the GAB, Peleg, Oswin, and Henderson models were adjusted to equilibrium desorption isotherms isolated at temperatures $\left(20,25,30,35\right.$, and $\left.40{ }^{\circ} \mathrm{C}\right)$ for seeds fresh pumpkin (Table 6).

For the criteria analyzed, the Peleg model better fitted to pumpkin seed moisture desorption isotherms at temperatures up to $40{ }^{\circ} \mathrm{C}$, even though the GAB model resulted in slightly better temperature adjustments at $20^{\circ} \mathrm{C}$. The Peleg model was the best fit for the experimental data, as it presented coefficients of determination $\left(\mathrm{R}^{2}\right)$, above 0.97 , lower mean values of relative error $(\mathrm{p}<0.1)$, and low estimated error (SE) at temperatures of 25, 30, 35 , and $40{ }^{\circ} \mathrm{C}$, also resulting in a satisfactory adjustment to the temperature of $20{ }^{\circ} \mathrm{C}$ for fresh pumpkin seeds (Table 6).

In the GAB model at 35 and $40{ }^{\circ} \mathrm{C}$, for the Oswin model at 30,35 and $40{ }^{\circ} \mathrm{C}$, and the Henderson model at all temperatures analyzed, mean relative error value was greater than $10 \%$ (Table 6), suggesting that their use should be avoided for the prediction of fresh pumpkin grain desorption isotherms at these temperatures. The result corroborates Costa et al. (2013) that when determining the moisture desorption isotherms of wheat grains, they did not have good adjustments with the Henderson model, which presented relative average errors higher than $10 \%$. 
Table 2. Relative humidity $(\mathrm{RH})$ and water activity $\left(\mathrm{a}_{\mathrm{w}}\right)$ according to the saturated solutions and pre-set temperatures for the determination of hygroscopic balance.

\begin{tabular}{cccc}
\hline Saturated solution & Nomenclature & $\begin{array}{c}\mathrm{RH} \\
(\%)\end{array}$ & $\begin{array}{c}\mathrm{a}_{w}^{*} \\
\text { (decimal) }\end{array}$ \\
\hline Potassium hydroxide & $\mathrm{KOH}$ & 11 & 0.11 \\
Potassium acetate & $\mathrm{CH}_{2} \mathrm{CO}_{2} \mathrm{~K}$ & 22 & 0.22 \\
Potassium carbonate & $\mathrm{K}_{2} \mathrm{CO}_{3}$ & 33 & 0.33 \\
Magnesium chloride & $\mathrm{MgCl}_{2}$ & 44 & 0.44 \\
Calcium nitrate & $\mathrm{Ca}\left(\mathrm{NO}_{3}\right)_{2}$ & 55 & 0.55 \\
Sodium chloride & $\mathrm{NaCl}$ & 66 & 0.66 \\
Potassium chloride & $\mathrm{KCl}$ & 77 & 0.77 \\
Barium chloride & $\mathrm{BaCl}_{2}$ & 88 & 0.88 \\
\hline
\end{tabular}

* Water activity $\left(\mathrm{a}_{\mathrm{w}}\right)$ varies $( \pm 0.2)$ depending on ambient conditions in constant relative humidity.

Table 3. Mean values of equilibrium humidity of fresh pumpkin seeds according to the water activity (aw) at different temperatures analyzed.

\begin{tabular}{cccccccccccc}
\hline \multirow{2}{*}{$\mathrm{a} w^{*}$} & \multicolumn{10}{c}{ Equilibrium humidity (decimal) } \\
\cline { 2 - 12 } & $10{ }^{\circ} \mathrm{C}$ & $20{ }^{\circ} \mathrm{C}$ & $25^{\circ} \mathrm{C}$ & $15 / 35^{\circ} \mathrm{C}$ & $30^{\circ} \mathrm{C}$ & $35^{\circ} \mathrm{C}$ & $40{ }^{\circ} \mathrm{C}$ & $43^{\circ} \mathrm{C}$ & $50{ }^{\circ} \mathrm{C}$ & $60{ }^{\circ} \mathrm{C}$ & $70{ }^{\circ} \mathrm{C}$ \\
\hline 0.11 & 0.0804 & 0.0781 & 0.0646 & 0.0736 & 0.0671 & 0.0764 & 0.0715 & 0.0604 & 0.0772 & 0.0681 & 0.0653 \\
0.22 & 0.1320 & 0.1210 & 0.0736 & 0.0924 & 0.1100 & 0.1137 & 0.1033 & 0.0893 & 0.0989 & 0.0828 & 0.0687 \\
0.33 & 0.1550 & 0.1503 & 0.1560 & 0.1434 & 0.1299 & 0.1442 & 0.1189 & 0.1040 & 0.1163 & 0.0989 & 0.0730 \\
0.44 & 0.1786 & 0.1571 & 0.1624 & 0.1170 & 0.1501 & 0.1578 & 0.1338 & 0.1058 & 0.1245 & 0.1163 & 0.0830 \\
0.55 & 0.1849 & 0.1742 & 0.1911 & 0.1512 & 0.1506 & 0.1584 & 0.1437 & 0.1156 & 0.1348 & 0.1255 & 0.0879 \\
0.66 & 0.2046 & 0.1917 & 0.1744 & 0.1801 & 0.1768 & 0.1939 & 0.1522 & 0.1190 & 0.1432 & 0.1318 & 0.0962 \\
0.77 & 0.2117 & 0.2045 & 0.1916 & 0.1868 & 0.1883 & 0.1839 & 0.1610 & 0.1236 & 0.1506 & 0.1409 & 0.1136 \\
0.88 & 0.2156 & 0.2114 & 0.2332 & 0.2135 & 0.2078 & 0.1845 & 0.1793 & 0.1790 & 0.1654 & 0.1533 & 0.1205 \\
\hline
\end{tabular}

Table 4. Estimated parameters and coefficients of determination $\left(\mathrm{R}^{2}\right)$ from experimental data for pumpkin seed hygroscopic equilibrium water content $(\mathrm{db})$ for each temperature analyzed.

\begin{tabular}{ccccc}
\hline Temperature & \multicolumn{3}{c}{ Parameters } & \multirow{2}{*}{$\mathrm{R}^{2}$} \\
\cline { 2 - 4 }$\left({ }^{\circ} \mathrm{C}\right)$ & $\mathrm{a}$ & $\mathrm{b}$ & $\mathrm{c}$ & 0.98717000 \\
10 & 0.04702440 & 0.00378797 & 0.00002148 & 0.93642893 \\
20 & 0.07969286 & 0.00166833 & 0.05130000 & 0.92463090 \\
25 & 0.08226071 & 0.00664466 & 0.00050920 & 0.92625946 \\
$15 / 35$ & 0.05930595 & 0.00172648 & 0.00000000 & 0.97716000 \\
30 & 0.09635761 & 0.00644029 & 0.00004709 & 0.94515087 \\
35 & 0.04363571 & 0.00351230 & -0.00002098 & 0.99862415 \\
40 & 0.02950476 & 0.00454154 & -0.00006634 & 0.97429289 \\
43 & 0.00003333 & 0.00679333 & -0.00014219 & 0.99887762 \\
50 & 0.04572857 & 0.00331718 & -0.00004559 & 0.99921595 \\
60 & 0.06413393 & 0.00042237 & 0.00008679 & 0.99415519 \\
\hline 0
\end{tabular}

Table 5. Estimated parameters, coefficients of determination $\left(\mathrm{R}^{2}\right)$, relative average error $(\mathrm{P})$, and error estimated (SE) for each hygroscopicity equation analyzed for pumpkin seeds.

\begin{tabular}{|c|c|c|c|c|c|c|}
\hline \multirow{2}{*}{ Model } & \multicolumn{3}{|c|}{ Parameters } & \multirow{2}{*}{$\mathrm{R}^{2}$} & \multirow{2}{*}{$\begin{array}{c}\mathrm{P} \\
(\%)\end{array}$} & \multirow{2}{*}{$\begin{array}{c}\mathrm{SE} \\
\text { (decimal) }\end{array}$} \\
\hline & $\mathrm{a}$ & $\mathrm{b}$ & $\mathrm{c}$ & & & \\
\hline Chung Pfosf & 0.8981 & 0.1551 & 130.3261 & 96.76 & 04.69 & 0.0019 \\
\hline Copace & -3.4961 & 0.0049 & 3.0293 & 98.84 & 03.12 & 0.0088 \\
\hline Modified GAB & 0.0996 & 0.9117 & 130.9347 & 84.55 & 09.92 & 0.0318 \\
\hline Modified Halsey & -8.3663 & 0.0211 & 3.8969 & 98.86 & 03.04 & 0.0105 \\
\hline Modified Henderson & 0.0201 & 177.2461 & 0.9259 & 94.88 & 06.39 & 0.0183 \\
\hline GAB & 6.079 & 47.6021 & 0.7738 & 96.39 & 08.52 & 0.0018 \\
\hline Henderson & 0.0139 & 0.9176 & - & 91.07 & 10.58 & 0.0497 \\
\hline Oswin & 0.1386 & -0.0002 & 1.5287 & 73.76 & 12.09 & 0.0414 \\
\hline Sabbah & 1.1102 & 2.0171 & 0.1922 & 89.60 & 09.07 & 0.0261 \\
\hline Sigma Copace & -4.5265 & 0.0049 & 1.6389 & 98.77 & 02.80 & 0.0090 \\
\hline Peleg & - & - & - & - & - & - \\
\hline
\end{tabular}


Table 6. Parameters of the GAB, Peleg, Oswin, and Henderson models adjusted to the desorption isotherms of fresh pumpkin seeds.

\begin{tabular}{|c|c|c|c|c|c|c|}
\hline \multirow{2}{*}{ Model } & \multirow{2}{*}{ Parameter } & \multicolumn{5}{|c|}{ Temperature } \\
\hline & & $20^{\circ} \mathrm{C}$ & $25^{\circ} \mathrm{C}$ & $30^{\circ} \mathrm{C}$ & $35^{\circ} \mathrm{C}$ & $40^{\circ} \mathrm{C}$ \\
\hline \multirow{5}{*}{ GAB } & $\mathrm{C}$ & 96.2102 & 87.6021 & 41.8818 & 23.2981 & 4.7143 \\
\hline & $\mathrm{K}$ & 0.8765 & 0.7774 & 0.8681 & 0.7225 & 0.5768 \\
\hline & $\mathrm{R}^{2}$ & 0.9892 & 0.9639 & 0.9607 & 0.9513 & 0.9419 \\
\hline & $\mathrm{P}$ & 0.0348 & 0.08521 & 0.0798 & 0.1103 & 0.1410 \\
\hline & SE & 0.0089 & 0.0115 & 0.0125 & 0.0133 & 0.0149 \\
\hline \multirow{7}{*}{ Peleg } & $\mathrm{k}_{1}$ & 22.9190 & 14.2888 & 5.6586 & 3.3121 & 0.9656 \\
\hline & $\mathrm{n}_{1}$ & 5.3144 & 2.72305 & 0.1317 & -0.1302 & -0.3921 \\
\hline & $\mathrm{k}_{2}$ & 10.609 & 14.3109 & 18.0128 & 17.0904 & 16.168 \\
\hline & $\mathrm{n}_{2}$ & 0.3542 & 1.5816 & 2.8090 & 2.0759 & 1.3428 \\
\hline & $\mathrm{R}^{2}$ & 0.9866 & 0.9785 & 0.9708 & 0.9705 & 0.9703 \\
\hline & $\mathrm{P}$ & 0.0451 & 0.0604 & 0.0757 & 0.0774 & 0.0790 \\
\hline & SE & 0.0011 & 0.0015 & 0.0010 & 0.0013 & 0.0099 \\
\hline \multirow{5}{*}{ Oswin } & A & 9.3370 & 8.7713 & 8.2056 & 8.0115 & 7.8174 \\
\hline & $\mathrm{B}$ & 0.4156 & 0.4216 & 0.4276 & 0.3445 & 0.2613 \\
\hline & $\mathrm{R}^{2}$ & 0.9852 & 0.97575 & 0.9663 & 0.9271 & 0.8877 \\
\hline & $\mathrm{P}$ & 0.0662 & 0.08865 & 0.1111 & 0.1533 & 0.1955 \\
\hline & SE & 0.0415 & 0.0418 & 0.0443 & 0.0419 & 0.0414 \\
\hline \multirow{5}{*}{ Henderson } & $\mathrm{A}$ & 0.1168 & 0.1422 & 0.1676 & 0.1643 & 0.161 \\
\hline & $\mathrm{B}$ & 1.7323 & 1.6179 & 1.5035 & 1.56245 & 1.6214 \\
\hline & $\mathrm{R}^{2}$ & 0.9717 & 0.95645 & 0.9412 & 0.95435 & 0.9675 \\
\hline & $\mathrm{P}$ & 0.1792 & 21.635 & 0.2535 & 0.23865 & 0.2238 \\
\hline & SE & 0.0088 & 0.0397 & 0.0227 & 0.0497 & 0.0997 \\
\hline
\end{tabular}

From the results presented (Table 5), inserting the model parameters determined in this study, both the Copace Equation and modified Halsey Equation (Table 1), is representative of the hygroscopicity phenomenon for the seed pumpkin. Regarding the hygroscopicity phenomenon, we present the equilibrium water content experimental values and the sorption isotherm values for Copace model (Figure 2) that show the best fit to the experimental data.

According to the Copace model, experimental and estimated values for equilibrium water content suggest an exponential increase in pumpkin seed of water activity as the relative humidity increases in the environment. In turn, by the modified Halsey model, the hygroscopicity phenomenon presented second-order polynomial behavior (Figure 3).

From the obtained results (Figure 3), it was possible to verify that the modified Halsey model ranges between 11 and $88 \pm 2 \%$ relative humidity, and at temperatures from 10 to $70{ }^{\circ} \mathrm{C}$, it describes the hygroscopic behavior of pumpkin seeds adequately when subjected to different environmental conditions.

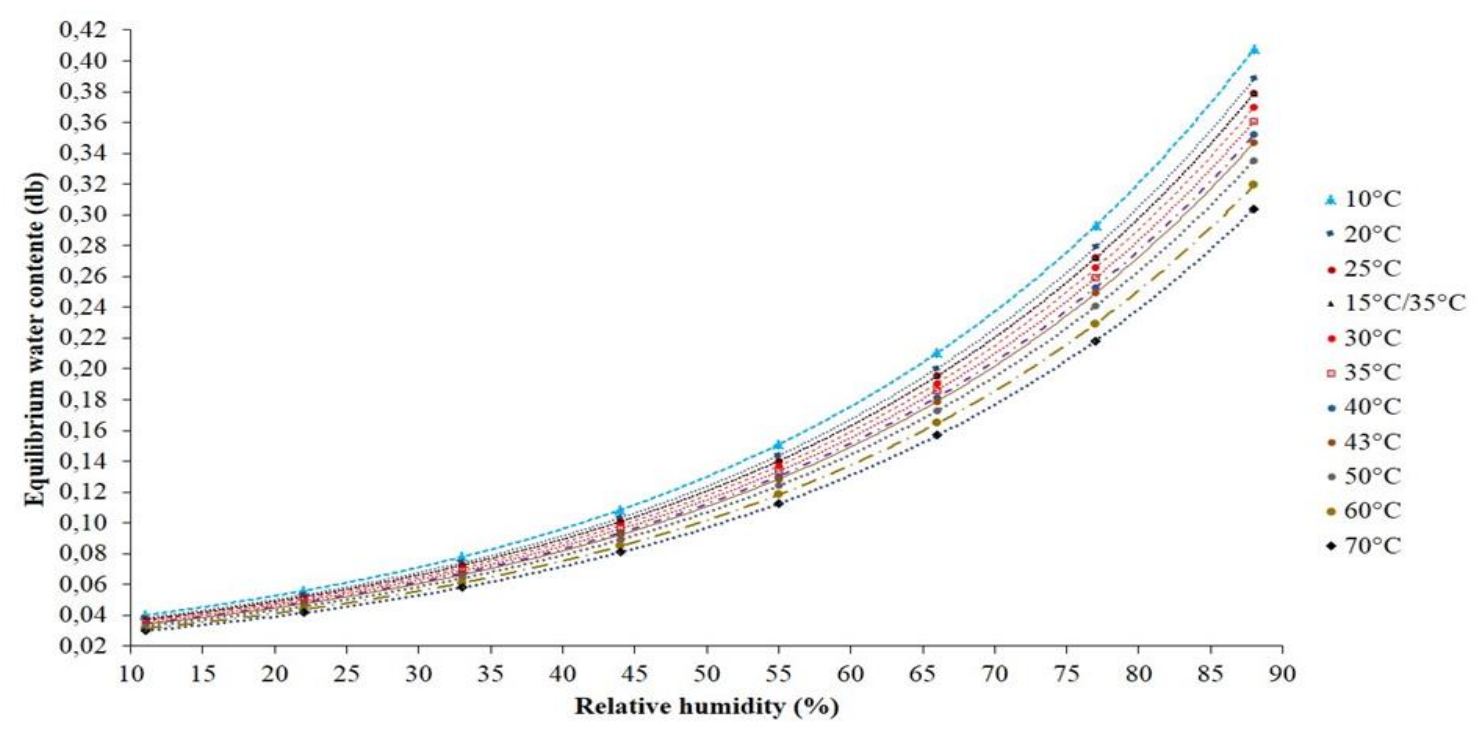

Figure 2. Experimental values estimated by the Copace model $\mathrm{f}$ equilibrium water content according to the water activity and temperature. 


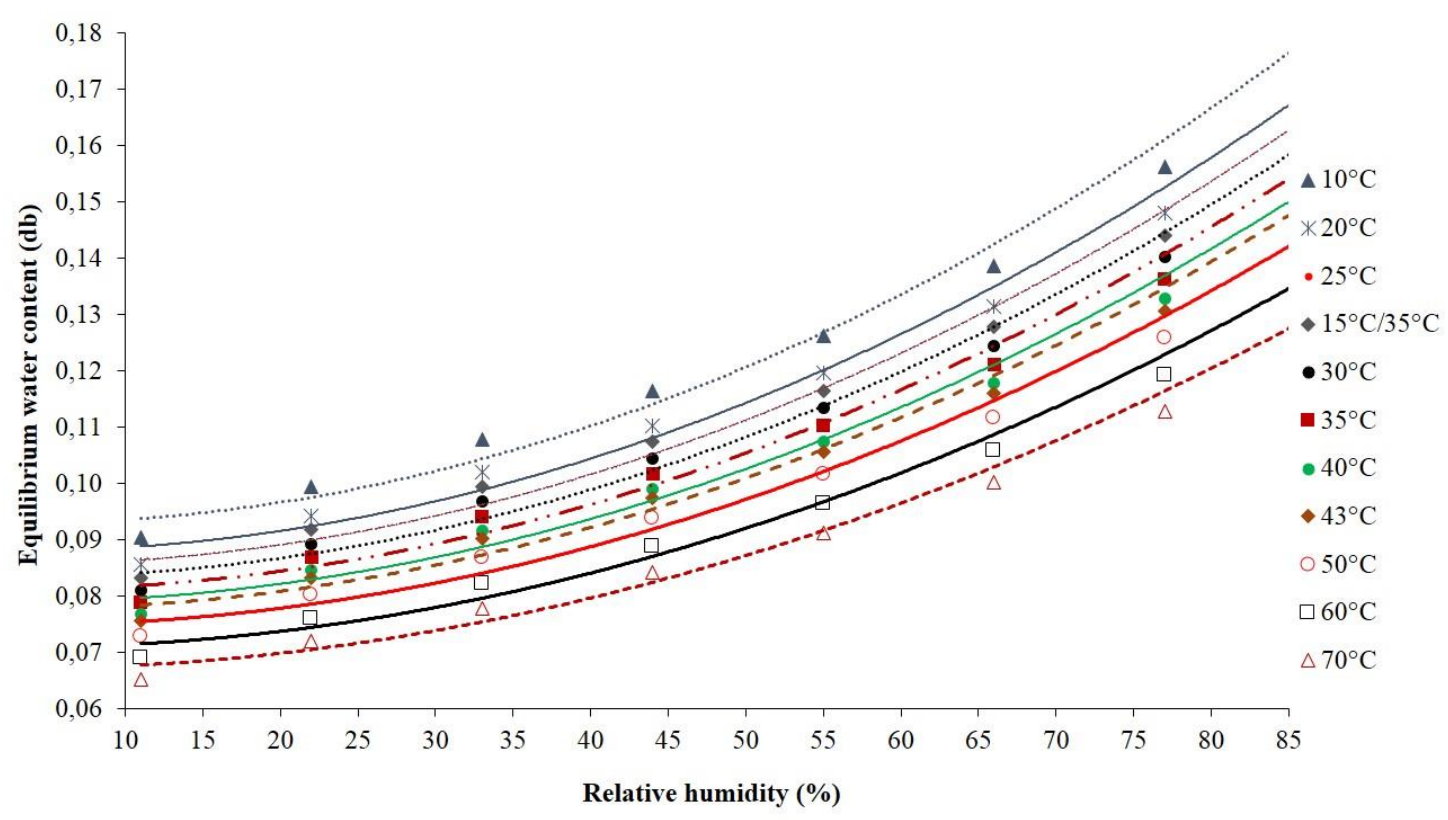

Figure 3. Experimental values estimated by the modified Halsey model of equilibrium water content according to the water activity and temperature.

From the results (Figures 2 and 3 ) in the same relative humidity, it is possible to verify that the estimated equilibrium water content values obtained a better fit with the modified Halsey model when compared to the values reported by the Copace model. The Copace model for the same environment with high relative humidity had estimated equilibrium water content much above the experimental values. At low relative humidity, the adjustment presented values much lower than the observed data.

About the geometric characteristics of pumpkin seed conditioned to different environmental conditions, the environmental conditioning saline solution (Table 2) did not affect seed size (length, width, and thickness). The protection against enzymatic and oxidative degradation, reducing its weight through post-harvest processes, generates energy savings for product conservation (Toivonen, 2004). Nóbrega et al. (2014) suggest the concentration of bioactive components, antioxidant activity, and physical-chemical characteristics can be altered as a function of drying conditions.

In the studied conditions, for the different contents of equilibrium water, it verified that the relative humidity did not affect the geometric characteristics of the seed, in equilibrium with the environment. The variation in volume shows a direct relationship between pumpkin seed size.

For temperatures below $45{ }^{\circ} \mathrm{C}$, similar values in the orthogonal seed axes suggest low-intensity cell contraction, possibly reflecting slow energy transfer to water activity or water evaporation. On the other hand, at the different environmental conditions allied to the temperature increase $\left(>45^{\circ} \mathrm{C}\right)$, the intensity of the water activity may influence the phenomenon of cellular contraction/expansion (Saath et al., 2010), causing a reduction in the geometric volume of the seed (Figure 4).

Relative humidity and temperature conditions during storage, where the product reaches the specific hygroscopic equilibrium, regardless of time, will determine the maintenance of its qualitative potential (Costa et al., 2013; Dalpasquale et al., 2012). Similar to that reported by Mohsenin (1986), it observed that the phenomenon of volumetric expansion caused changes in the dimension of pumpkin seed orthogonal axes, with greater expression at 60 and $70{ }^{\circ} \mathrm{C}$ (Figure 4).

About the hygroscopicity phenomenon at temperatures (50, 60 and $70{ }^{\circ} \mathrm{C}$ ), the warmer air imposed a greater mass/energy exchange, changing the seed volume, since the water was removed at a higher speed, contracting the axes according to the reduction in water content of pumpkin seed (Figure 4). Seed weight decreased as the amount of water available decreased.

The loss of cell membrane integrity and reduction of respiration and biosynthesis activities is directly proportional to the increased release of seed solutes. The direct effect of the environmental conditions on the variation of the EC values $\left(\mu \mathrm{S} \mathrm{cm} \mathrm{cm}^{-1} \mathrm{~g}^{-1}\right)$ is an indirect evaluation of the state of cell membrane organization using the electrical conductivity test (EC) to measure the amount of leachate in the soaking solution. Due to increases in temperature and relative humidity, initial events of the deterioration process resulted in higher EC values (Figure 5 ), whose increase in temperature suggests a reduction in the physiological quality of pumpkin seeds. 


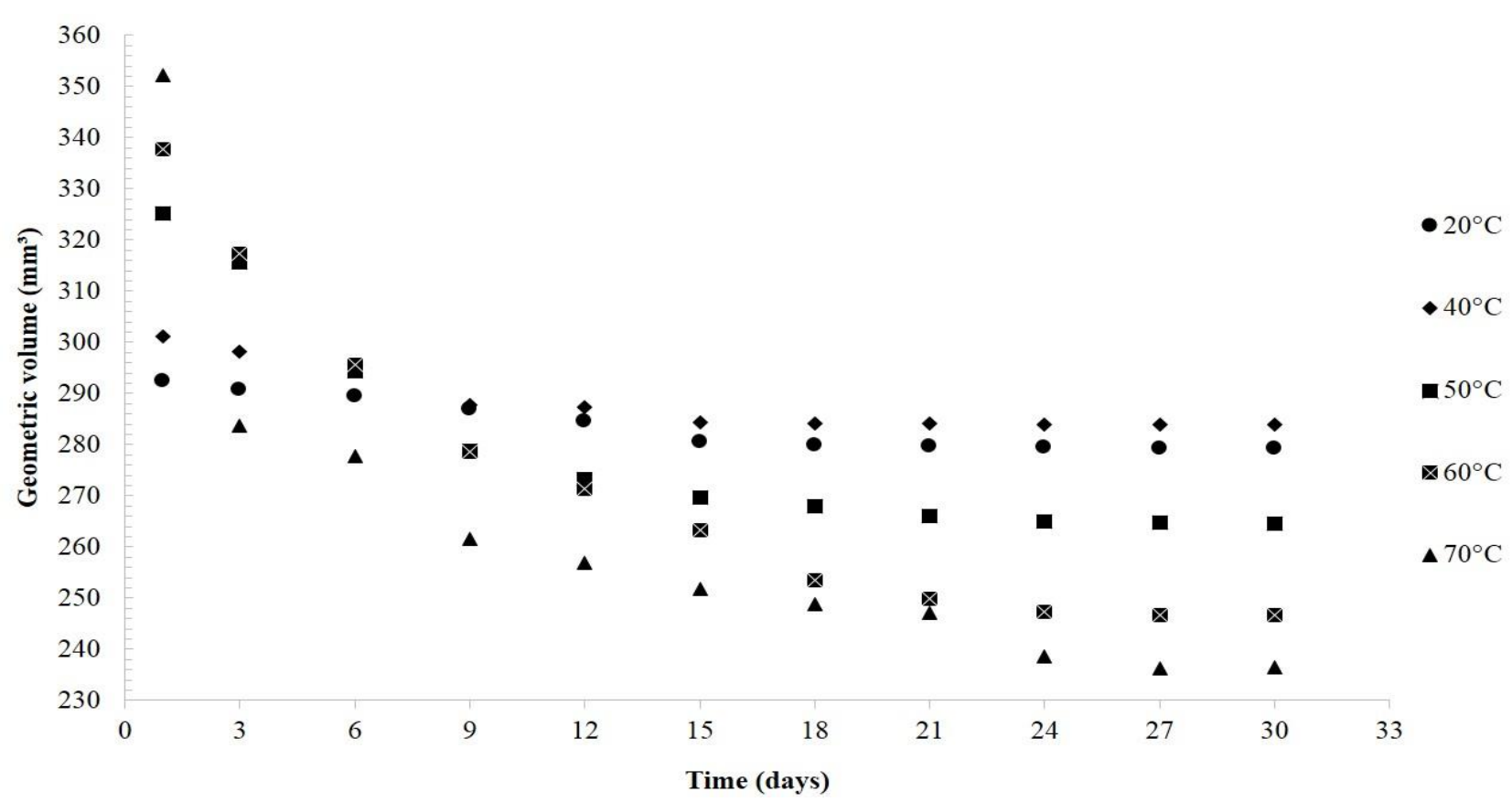

Figure 4. Pumpkin seed geometric volume for different equilibrium water content (db) according to the time and ambient temperature.

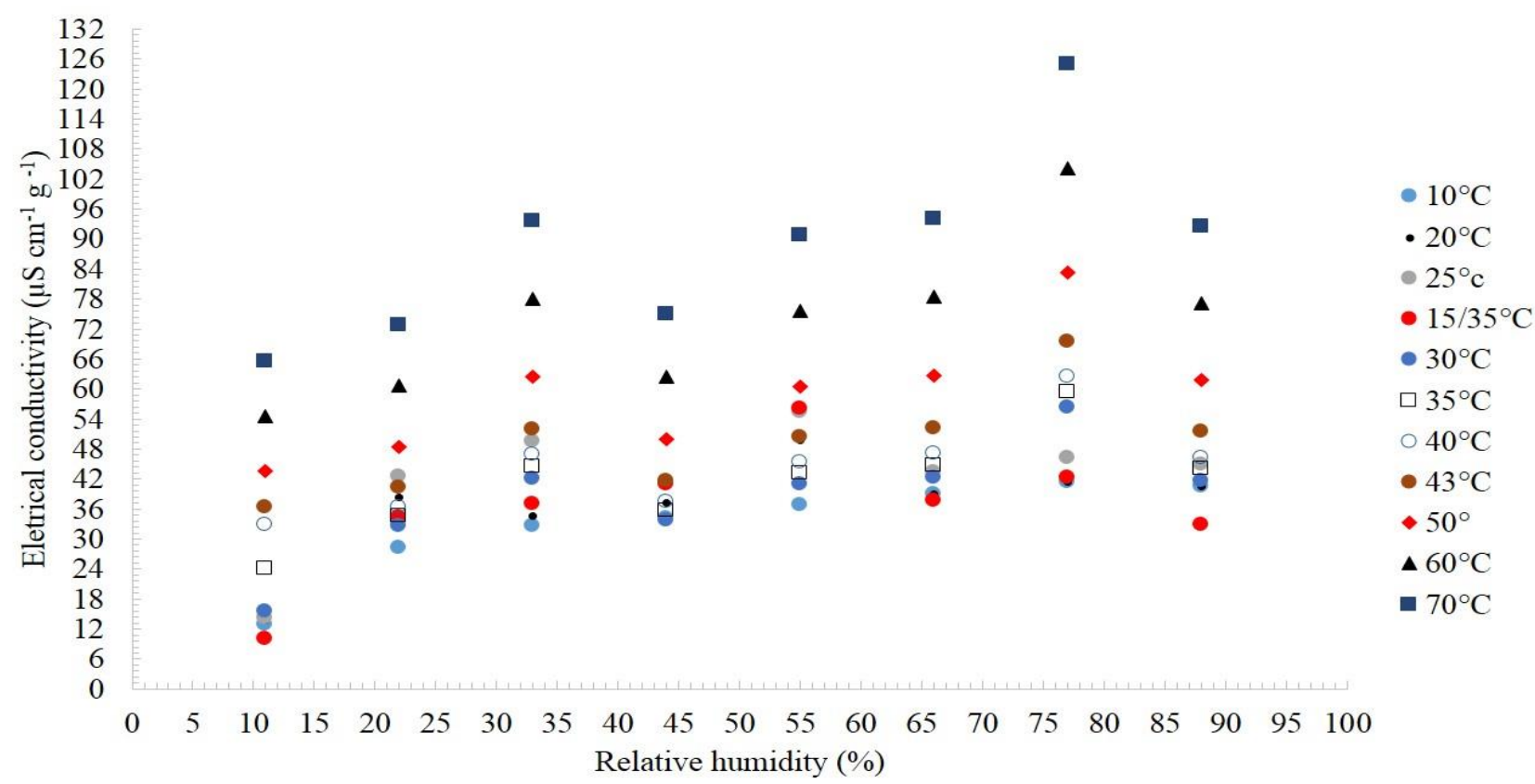

Figure 5. Electrical conductivity $\left(\mu \mathrm{S} \mathrm{cm}^{-1} \mathrm{~g}^{-1}\right)$ of pumpkin seeds with equilibrium water content $(\mathrm{db})$ with the environment according to the air temperature and relative humidity.

When considering seed storage, for the studied water contents and the conditions (temperatures and relative humidity) analyzed, there is a growing release of electrolytes from the seeds to the soaking water, which is indicative of loss of vigor and physiological quality in storage. Researchers who evaluated the physiological quality of different seeds stored under different conditions (Belmiro et al., 2010; Oliveira et al., 2012; Silva et al., 2010; Zuchi et al., 2013) also observed this fact. This is directly related to respiratory activities (Oliveira et al., 2016), and lipid peroxidation may be the most frequent cause of seed deterioration and viability loss (Abreu et al., 2013).
Also, the lower the water content, the greater the amount of energy needed for the seed to come into balance with the environment. In this context, Siqueira et al. (2011) found that the decrease in geometric diameter is proportional to the reduction in water content, which also depends on the method and conditions of the drying environment, and the temperature and relative humidity of the drying air (Saath et al., 2010). Regarding volume reduction, moisture content reductions influenced seed volume, and the higher the air temperature, the greater the effects on soybean seed volume reduction and physical quality (Coradi et al., 2016). 


\section{Conclusions}

Hygroscopic seed balance was directly proportional to water activity and decreased with increasing temperature to the same water activity value.

Pumpkin seeds maintained water content $(<0.10)$ at storage conditions of relative humidity $<55 \%$ and temperature of 60 and $70{ }^{\circ} \mathrm{C}$ or relative humidity $<25 \%$ to all temperatures

The modified Halsey model better represented the hygroscopicity of pumpkin seeds.

\section{Acknowledgments}

To State University of Maringá (UEM) for structure availed for research. This study was financed in part by the Coordenação de Aperfeiçoamento de Pessoal de Nível Superior - Brasil (CAPES) - Finance Code 001.

\section{Bibliographic References}

Abreu, L.A.S., Carvalho, M.L.M., Pinto, C.A.G., Kataoka, V.Y., Silva, T.T.A., 2013. Deterioration of sunflower seeds during storage. Journal of Seed Science, 35(2), 240-224.

AOAC, 2019. Official methods of analysis of the Association of Official Analytical Chemists, 21th ed. Gaithersburg, Maryland.

Barbosa, K.F., Sales, J.F., Resende, O., Oliveira, D.E.C., Zuchi, J., Sousa, K.A., 2016. Desorption isotherms and isosteric heat of "cajuzinho-do-cerrado" achenes. Revista Brasileira de Engenharia Agrícola e Ambiental, 20(5), 481-486.

Belmiro, T.M.C., Queiroz, A.J.M., Figueirêdo, R.M.F., Fernandes, T.K.S., Bezerra, M.C.T., 2010. Alterações químicas e físico-químicas em grãos de abóbora durante o armazenamento. Revista Brasileira de Engenharia Agrícola e Ambiental, 14(9), 1000-1007.

Bustos-Vanegas, J.D., Corrêa, P.C., Zeymer, J.S., Baptestini, F.M., Campos, R.C., 2018. Moisture sorption isotherms of quinoa seeds: thermodynamic analysis. Engenharia agrícola, 38(6), 941-950.

Coradi, P.C., Fernandes, C.H.P., Helmich, J.C., Goneli, A.L.D., 2016. Effects of drying air temperature and grain initial moisture Content on soybean quality (Glycine max (L.) Merrill). Journal of the Brazilian Association of Agricultural Engineering, 36(5), 866-876.

Costa, L.M., Resende, O., Oliveira, D.E.C., 2013. Isotermas de dessorção e calor isostérico dos frutos de crambe. Revista Brasileira de Engenharia Agrícola e Ambiental, 17(4), 412-418.

Costa, L.M., Resende, O., Oliveira, D.E.C., Sousa, K.A., 2015. Isotermas e calor isostérico de sementes de Buchenavia capitata (Vahl) Eichler. Revista Ciência Agronômica, 46(3), 516-523.

Dalpasquale, V.A., Sperandio, D., Silva, L.H.M., 2012. Fixedbed drying simulation with constant enthalpy, using the improved Michigan State University model. Acta Scientiarum Technology, 34(2), 137-140.
Diógenes, A.M.G., Queiroz, A.J.M., Figueiredo, R.M.F., Santos, D.C., 2013. Cinética de secagem de grãos de abóbora. Revista Caatinga, 26(1), 71-80.

Greenspan, L., 1977. Humidity fixed points of binary saturated aqueous solutions. Journal of Research of National Bureau of Satandards, 81(1), 89-96.

Guimarães, R.M., Oliveira, D.E.C., Resende, O., Silva, J.S., Rezende, T.A.M., Egea, M.B., 2018. Thermodynamic properties and drying kinetics of "okara". Revista Brasileira de Engenharia Agrícola e Ambiental, 22(6), 418-423.

Martins, L.H.P., Noda, H., Lopes, M.T.G., Mendonça, M.S.P., Martins, A.L.U., 2016. Genetic Variability of Pumpkin Landraces in Brazilian Amazon. Agricultural Sciences, 7, 822-833.

Mohsenin, N.N., 1986. Physical properties of plant and animal materials. Gordon and Breach Publishers, New York.

Nóbrega, E.M., Oliveira, E.L., Genovese, M.I., Correia, R.T.P., 2014. The impact of hot air drying on the physicalchemical characteristics, bioactive compounds and antioxidant activity of acerola (Malphigia emarginata) residue. Journal of food processing and preservation, 39(2), 131-141.

Oliveira, A.S., Carvalho, M.L.M., Bárbara, C.N.V., Guimarães, R.M., Oliveira, J.A., Pereira, D.S., 2016. Biochemical changes in fber naturally colored cottonseeds during storage. Journal of Seed Science, 38(2), 101-109.

Oliveira, F.N., Torres, S.B., Vieira, F.E.R., Paiva, E.P., Dutra, A.S., 2012. Qualidade fisiológica de sementes de girassol avaliadas por condutividade elétrica. Pesquisa Agropecuária Tropical, 42(3), 279-287.

Pereira, R.Z., Damaceno, J.B.D., 2018. Tecnologia de secagem de sementes de soja. Revista DELOS, 11(31), 1-10.

Saath, R., Borém, F.M., Alves, E., Taveira, J.H.S., Medice, R., 2010. Microscopia eletrônica de varredura do endosperma de café (Coffea arabica L.) durante o processo de secagem. Ciência e Agrotecnologia, 34(1), 196-203.

Saath, R., Wenneck, G.S., Santi, D.C., Araújo, L.L., Rezende, R., 2019. Alternativas para secagem de sementes: consumo energético do sistema de qualidade da semente de abóbora em função do processo de secagem. Brazilian Journal of Development, 5(11), 24980-24989.

Santos Júnior, L.C.O., Simão, V., Almeida, J.S.O., Aquino, A.C.M.S., Carasek, E., Amante, E.R., 2017. Study of heat treatment in processing of Pumpkin Puree (Cucurbita moschata). Journal of Agricultural Science, 9(10), 234-243.

Severino, K.L.P., Crepaldi, J., Zeuini, V.M., Monteiro, A.R., Pedro, M.A.M., Damy-Benedetti, P.C., Cattelan, M.G., Veronezi, C.M., 2019. Potencial uso de sementes de abóbora (Curcubita moschata) como aproveitamento de resíduo. Revista Científica UNILAGO, 1(1), 1-10.

Silva, F.S., Porto, A.G., Pascuali, L.C., Silva, F.T.C., 2010. Viabilidade do armazenamento de sementes em diferentes embalagens para pequenas propriedades rurais. Revista de Ciências Agro-ambientais, 8(1), 45-56. 
Silva, H.W., Costa, L.M., Resende, O., Oliveira, D.E.C., Soares, R.S., Vale, L.S.R., 2015. Higroscopicidade das sementes de pimenta (Capsicum chinense L.). Revista Brasileira de Engenharia Agrícola e Ambiental, 19(8), 780-784.

Siqueira, V.C., Resende, O., Chaves, T.H., 2011. Contração volumétrica dos frutos de pinhão-manso durante a secagem em diversas temperaturas. Revista Brasileira de Armazenamento, 36(2), 171-178.

Teixeira, L.P., Andrade, E.T., Devilla, I.A., 2018. Isosteric heat, entropy, and Gibbs free energy of pumpkin seeds (Cucurbita moschata). Revista Engenharia Agrícola, 38(1), 97102.

Thode Filho, S., Cabral, G.B., Maranhão, F.S., Sena, M.F.M., Silva, E.R., 2014. Deterioração de óleos vegetais expostos a diferentes condições de armazenamento. REGET, 18(Edição Especial), 07-13.
Toivonen, P.M.A., 2004. Postharvest storage procedures and oxidative stress. HortScience, 39(5), 938-942.

Ullmann, R., Resende, O., Oliveira, D.E.C., Costa, L.M., Chaves, T.H., 2016. Higroscopicidade das sementes de sorgosacarino. Engenharia Agrícola, 36(3), 515-524.

Veronezi, C.M., Jorge, N., 2012. Aproveitamento de sementes de abóbora (Cucurbita sp) como fonte alimentar. Revista Brasileira de Produtos Agroindustriais,14(1), 113-124.

Yang, Z., Zhu, E., Zhu, Z., 2012. Moisture sorption isotherm and net isosteric heats of sorption of green soybean. International Journal of Food Engineering, 8(3), 15-27.

Zuchi, J., França Neto, J.B., Sediyama, C.S., Lacerda Filho, A.F., Reis, M.S., 2013. Physiological quality of dynamically cooled and stored soybean seeds. Journal of Seed Science, 35(3), 353-360. 